\title{
Unleashing Workplace Innovation in Scotland
}

\author{
Rosemary Exton \\ Peter Totterdill
}

\begin{abstract}
Amid the turbulent political and economic developments around the British departure from the European Union (Brexit), practical activities around Workplace Innovation have continued. The UK Work Organisation Network established Workplace Innovation Ltd, which is now based in Dublin as Workplace Innovation Europe. This short article describes the promising new programme of work on Workplace Innovation in Scotland, working with the support of the Scottish Government. In the uncertainty of the months and years ahead in the UK, Scotland can offer a lead which can be followed by the other regjons and nations of the United Kingdom.
\end{abstract}

Keywords: Engagement, Fifth Element, Participation, Productivity, Scotland, Workplace Innovation 


\section{Introduction}

The concept of workplace innovation emerged at the end of the last present century as a systemic and dynamic view of organisations and organisational change. It recognises that attempts to improve organisational performance or working life are likely to be futile unless a company aligns its work organisation, systems, procedures, management behaviours, organisational structure, corporate values and leadership towards the same ends. In short, organisations are seen as systems of interdependent and continually changing parts.

The keynote Hi-Res study prepared for the European Commission in 2002 argued that the defining characteristic of workplace innovation lay in the creation of jobs and practices that "empowered workers at every level of an organisation to use and develop their full range of knowledge, skills, experience and creativity in their day-to-day work", emphasising the critical link between empowerment, learning, innovation and productivity. Workplace innovation thereby addresses a wide range of pressing policy issues for national and regional governments in Europe including productivity, product and service innovation, skills utilisation, demographic change, and health and wellbeing at work. More recently, Oeij et al (2017) have provided a comprehensive overview of the theory, practice and implications of workplace innovation for businesses, social partners, policymakers and other stakeholders.

This article explores the significance of the Workplace Innovation Engagement Programme (WIEP) in Scotland, a policy intervention designed to address the persistence of low productivity, and to promote the Scottish Government's goals of 'Fair Work' and 'Inclusive Growth'. We analyse the experiences of the nineteen very diverse companies that took part in two programme cohorts between November 2016 and mid-2018, including narrative accounts from participants and employee survey data. The challenges and dilemmas associated with its methodology design, implementation and evaluation are also considered.

\section{The Workplace Innovation Engagement Programme}

The devolution of certain powers from the UK to an elected Scottish Parliament has opened a different trajectory for economic development and industrial policy in Scotland.

Workplace innovation has been adopted as a key policy strand within the Scottish Government's Inclusive Growth strategy and its Fair Work Framework, both grounded in a commitment to win-win-win outcomes for companies and people: high levels of economic performance, high quality of working life and a high skill equilibrium in the labour market.

Scottish Enterprise, the country's economic development agency, instigated an extensive programme of awareness raising workshops, masterclasses and support services designed to increase the adoption of workplace innovation by Scottish companies, and this portfolio included the pilot Workplace Innovation Engagement Programme (WIEP). Workplace Innovation Limited, a not-for-profit organisation led by the authors of this article, was selected by Scottish Enterprise to deliver the programme.

The first cohort of ten companies was recruited by Scottish Enterprise in Autumn 2016, and a second cohort of nine companies entered the programme in September 2017. Both cohorts represented considerable diversity in terms of size, sector and geographical location. 'Engagement' in one form or another was cited by the majority of companies as the principal motivation for joining the programme, whether to support anticipated growth, manage internal restructuring, or to address a 'burning platform' created by changing market conditions. 


\section{Defining workplace innovation}

The conceptual framework for the programme was provided by 'The Essential Fifth Element'3, a concept developed by Workplace Innovation Limited for the European Commission's EUWIN network to explain the benefits of workplace innovation and provide practical guidance on making change happen. An analysis of more than two hundred articles and case studies found a strong association between high performance and high quality of working life on the one hand, and four bundles (or 'Elements') of working practices on the other. Much of this evidence emphasised the interdependent nature of these practices, and the importance of aligning them to form a system of mutually reinforcing parts (Teague, 2005). The 'Fifth Element', or convergence between high performance and high quality of working life, is created by this alchemy (Totterdill, 2015).

\begin{tabular}{|c|c|c|}
\hline Element & Indicative Practices & Association \\
\hline Jobs and Teams & $\begin{array}{l}\text { Individual discretion } \\
\text { Job variety } \\
\text { Constructive challenges } \\
\text { Self-managed teams } \\
\text { Collaboration within the team } \\
\text { Reflective team practices }\end{array}$ & $\begin{array}{l}\text { Improved workflow } \\
\text { Enhanced quality } \\
\text { Better productivity } \\
\text { Cost reduction } \\
\text { Engagement and retention } \\
\text { Improved workforce health }\end{array}$ \\
\hline $\begin{array}{l}\text { Employee-Driven Innovation } \\
\text { \& Improvement }\end{array}$ & $\begin{array}{l}\text { Productive reflection in teams } \\
\text { Cross-team improvement } \\
\text { groups } \\
\text { Company-wide innovation } \\
\text { events }\end{array}$ & $\begin{array}{l}\text { Enhanced capacity for } \\
\text { innovation \& improvement } \\
\text { Enhanced quality \& } \\
\text { performance } \\
\text { Learning \& development } \\
\text { Engagement \& retention } \\
\text { Intrinsic job satisfaction }\end{array}$ \\
\hline $\begin{array}{l}\text { Organisational Structures, } \\
\text { Management and Procedures }\end{array}$ & $\begin{array}{l}\text { Reduced hierarchies and silos } \\
\text { Strengths-based career } \\
\text { structure } \\
\text { Coaching style line } \\
\text { management } \\
\text { Simplified procedures }\end{array}$ & $\begin{array}{l}\text { Improved workflow } \\
\text { Cost reduction } \\
\text { Better productivity } \\
\text { Engagement \& retention } \\
\text { Improved workforce health }\end{array}$ \\
\hline $\begin{array}{l}\text { Co-Created Leadership \& } \\
\text { Employee Voice }\end{array}$ & $\begin{array}{l}\text { Openness and transparency } \\
\text { Visible leadership } \\
\text { Delegated decision-making } \\
\text { Representative participation }\end{array}$ & $\begin{array}{l}\text { Strategic alignment } \\
\text { Better decision-making } \\
\text { Engagement and retention }\end{array}$ \\
\hline
\end{tabular}

3 http://uk.ukwon.eu/the-fifth-element-new 
In addition to its value in promoting the concept of workplace innovation through EUWIN, The Essential Fifth Element was operationalised throughout WIEP. It provided the basis for the Diagnostic and Action Plans, and shaped the content of the Structured Learning, coaching and facilitation sessions.

\section{Impact of the Programme}

Evaluation of the programme's impact on business performance presents several challenges, not least because of the paucity of reliable and relevant 'before and after' performance measures at company level. While productivity is an understandable priority for policymakers, none of the 19 companies measured it directly nor were there readily identifiable surrogate indicators. A second, and equally challenging problem, is that of attributing changes in specific indicators to the programme itself. For example, one company achieved a $£ 1.4 \mathrm{~m}$ turnaround on profit without additional investment through increased volume and efficiency, entirely attributed by management to enhanced engagement and behaviour change. Yet this transformation had already started before WIEP, and there is no ready way of attributing a specific share of $£ 1.4 \mathrm{~m}$ to the programme.

We can draw two things from this example. Firstly, the attribution of a substantial profit turnaround exclusively to the introduction of practices related to workplace innovation is headline-grabbing in its own right, raising business awareness and strengthening the case for future public support. Outcomes from other companies may be less succinctly expressed but certainly add to this argument.

Secondly, it directs us to the key question underpinning this evaluation: did WIEP play a role in these transformations that was critical to the outcomes? Again, the answer cannot be entirely straightforward: who can untangle the multiple sources of inspiration or evidence that inform the introduction of an innovative work practice?

The assessment of outcomes is based on reports from participants during the programme sessions, anonymous survey responses and post project interviews. Each company participating in the programme made significant process improvements attributable wholly or in substantial part to WIEP. These process improvements led to faster throughput time, improved efficiency, more effective problem solving, enhanced competencies and/or greater capacity for innovation. In several cases, silo working has been reduced by enhanced collaboration between functional departments, leading to less bureaucracy and fewer conflicts or delays. By empowering teams, time previously spent on micro-management is freed up, leading to greater agility and speed of response.

Each of the companies also instigated mechanisms for stimulating and utilising employee ideas for product, service or process innovation, unleashing the potential for further wealth generation well into the future.

While few of the companies have quantified the economic benefits of these improvements, examples such as:

- the reduction of throughput time by nearly a third;

- the savings of $£ 100 \mathrm{k}$ on a single improvement project;

- the resolution of a business-critical problem;

- a $6 \%$ profit uplift in affected teams;

- all provide an indication of the overall benefits to the Scottish economy when aggregated across all nineteen organisations.

Each of the companies reports improved levels of engagement, validated in some cases by their internal engagement survey results as well as by our interviews. This is likely to be reflected in better mental and physical health, the retention of older workers and enhanced skills development for younger employees. This was wider implications for health and social policy in Scotland.

Multiplier effects can also be added to the assessment of impact. For those companies on a 'burning platform', these financial gains will help to protect existing jobs. Elsewhere on the scale, enhanced innovation capacity or improved competitive advantage is likely to stimulate further job growth. 
WIEP was designed specifically to enhance the competence of individual participants in terms of management and leadership skills, change facilitation and knowledge of workplace innovation, as well as to support them and their companies in introducing new working practices. Individual learning journeys were therefore important in securing wider outcomes for each company, and comments below place importance both on practical knowledge and soft skills acquired from the programme. Each individual participant reported important benefits in terms of personal learning and development. These can be summarised as:

- Enhanced knowledge and experience of workplace innovation.

- Exposure to wider experiences.

- Increased confidence.

- Ability to challenge established practice and influence others.

- Changed management style

- Encouraging curiosity and 'learning to learn'.

- Creative thinking.

- Peer-to-peer learning.

The importance of this is not limited to the individual alone; rather it reflects their continuing ability to drive positive changes forward in their companies. Over time, WIEP alumni will become an important asset for the future of the Scottish economy.

Sustainability of change and the avoidance of innovation decay lies at the heart of The Essential Fifth Element approach with its emphasis on the interdependent practices that can ensure the success or failure of changes. Each company considers that it has built a sustainable momentum of change through WIEP, though some recognise the need for further support especially those faced with adverse trading circumstances.

Finally, in evaluating the impact of WIEP it is also important to consider the costs of participation for the companies concerned. For most participants, WIEP involved a commitment of 8.5 days away from the workplace plus an estimated $4-8$ hours on the Fresh Thinking Labs platform. This would be a substantial commitment for a conventional leadership course in which there was only an indirect impact on the business. WIEP, however, offers a triple helix of benefits: personal development, practical support for workplace change and peer-to-peer network building. This combination of outcomes may explain the lack of any negative comment from participants about the overall time commitment. Overall, feedback suggested that the content of the sessions positively supported practical action in the workplace as well as personal learning, development and network building.

\section{Conclusion: WIEP's policy significance}

Feedback on the programme was overwhelmingly positive, focusing on the overall quality of support, the learning, sharing and 'camaraderie' between companies, and the practical outcomes stimulated by WIEP. The design, content and delivery of the programme appears to have been validated by participant feedback via the different sources mentioned above sources. Experience from both Cohorts shows that the programme's impact lies in 'the sum of the parts' rather than in any one or two components, and this is at the heart of the added value provided by WIEP compared with à la carte menus of business support offered by Scottish Enterprise and other agencies. Group-based programmes such as WIEP offer particular value for money for public agencies, firstly because the majority of expert time is focused on the cohort as a whole, and secondly because peer-to-peer support is clearly an important motivator and a valuable source of ideas which comes as part of the package without extra cost.

The case for workplace innovation in enabling Scotland to fulfil its Inclusive Growth and Fair Work goals is strong, backed by a body of multi-disciplinary research and international experience, and not least by the WIEP outcomes reported above.

WIEP as a generative resource for the design of future initiatives 
The UK has little history of policies or programmes designed to support workplace innovation. Only a minority of countries and regions currently enjoy proactive policy frameworks designed to promote workplace innovation: we are aware that these exist in the Basque Country (Spain), Finland, Flanders (Belgium), France, Germany, Norway, Singapore, South Korea and Sweden (Totterdill et al, 2016; Alasoini et al, 2017), whilst in Denmark such initiatives lie within the scope of its social partnership framework. Elsewhere workplace innovation tends not to be recognised in either skills or competitiveness policy frameworks. The importance of WIEP lies, in part, in its potential to demonstrate the potential of workplace innovation to a wider audience of UK policymakers.

Three notes of caution are required in addressing the design of future policy measures.

Firstly, policymakers need to adopt a long term perspective. The impact of programmes in countries such as Finland, France and Germany is closely related to their longevity, in some case covering more than four decades and representing a political consensus that creates resilience even when governments change. Policy funding cycles of two, three or even five years create uncertainty and lead to an overemphasis on short term delivery rather than building sustainable capacity.

Secondly, Ramstad draws attention to the importance of the wider social learning that can be generated by such programmes (Ramstad, 2009b). Experience from Finland and elsewhere shows that long term dissemination impacts are enhanced when a wider body of stakeholders are actively involved in programme implementation; these stakeholders include employers' organisations, chambers of commerce, trade unions, professional bodies, universities and other public agencies. This helps to ensure that workplace innovation forms a common agenda with a shared vocabulary amongst stakeholders, creating consistency in communication with enterprises and their employees. Scotland's approach to the promotion of workplace innovation is grounded in an explicit commitment to shared learning, both across the public sector and with the wider body of stakeholders.

Finally it is important to adopt a critical approach to the notion of 'transferability'. As with all policies and programmes, WIEP was created within a specific context, responding to needs and opportunities identified in one region. This case study has identified the broad characteristics and outcomes of the programme in the hope that WIEP can become a generative resource for policy innovation elsewhere, but such innovation will need to be grounded in its own specific economic, social, political and spatial setting.

\section{References}

Alasoini T., Ramstad R., Totterdill P. (2017) "National and regional policies to promote and sustain workplace innovation". In: Oeij P., Rus D., Pot F. Workplace Innovation: Theory, Research and Practice. Heidelberg: Springer.

Antila J. and Ylöstalo P. (1999), Functional Flexibility and Workplace Success in Finland, Ministry of Labour, Helsinki.

Appelbaum E., Bailey T., Berg P., Kalleberg A.L. (2000), Manufacturing Advantage: Why High-Performance Work Systems Pay Off. Ithaca, NY: ILR Press.

Borrill C., Carlette T., Carter,A., Dawson J., Garrod S., Rees A., Richards A., Sharpiro D., West M., (2001) The Effectiveness of Health Care Teams in the National Health Service. Aston University, University of Glasgow, University of Leeds, UK.

Broadberry S. N. \& Crafts N. F. R., (1992) "Britain's productivity gap in the 1930s: some neglected factors." Journal of Economic History. vol. 52(03), 531-558. 
Brödner P. and Latniak E. (2002). "Sources of innovation and competitiveness: national programmes supporting the development of work organisation." Final Report to DG Employment and Social Affairs, Institute for Work and Technology, Gelsenkirchen.

Business Decisions Ltd (2002), New forms of work organisation: the obstacles to wider diffusion. KE-47-02-115EN-C, DG Employment and Social Affairs, European Commission, Brussels.

CEDEFOP (2015), Matching skills and jobs in Europe: Insights from Cedefop's European skills and jobs survey. http://www.cedefop.europa.eu/en/publications-and-resources/publications/8088 (accessed 03.01.2016).

Delery J. E. and Doty D. H., (1996), "Modes of Theorizing in Strategic Human Resource Management: Tests of Universalistic, Contingency and Configurational Performance Predictions". Academy of Management Journal, 39 (4): 802-35.

Financial Times (2018) “The UK's corporate productivity challenge, in charts". www.ft.com/content/c78ff64cfc7f-11e7-9bfc-052cbba03425 (accessed 23rd July 2018).

Fricke W. and Totterdill P. eds. (2004) Action Research in Workplace Innovation and Regional Development. Amsterdam: John Benjamins.

Gambin L., Green A. and Hogarth,T. (2009) Exploring the links between skills and productivity: Final report. Warwick: Warwick Institute for Employment Research.

Green A. Low skill traps in sectors and geographies: underlying factors and means of escape. Coventry: Institute for Employment Research.

https://assets.publishing.service.gov.uk/government/uploads/system/uploads/attachment data/file/593923/LowSki 11sTraps- final.pdf (accessed 23rd July 2018).

Gustavsen, B. (1992). Dialogue and Development, Van Gorcum: Assen/Maastricht.

Harris L., Tuckman A., Watling D., Downes B. (2011) Unlocking Engagement: A Review of the 'Innovative Workplaces' Initiative. London: Acas.

ITPS (2001), Enterprises in transition: Learning strategies for increased competitiveness, ITPS: Östersund.

Keep E. (2014) Employment Relations Comment, October. London: Acas.

Lay G., Dreher C. and Kinkel S. (1996), Neue Produktionskonzepte leisten einen Beitrag zur Sicherung des Standorts Deutschland. ISI Produktionsinnovationserhebung Nr. 1, Fraunhofer-Institut für System- und Innovationsforschung (ISI), Karlsruhe, Germany.

LLAKES (2012) Skills and Employment Survey. Reports downloadable from www.llakes.org (03.01.2016)

NUTEK (1996) Towards Flexible Organisations. Stockholm: NUTEK.

Oeij P., Rus D. and Pot F. (eds.) (2017) Workplace innovation. Theory, research and practice. Cham, Switzerland: Springer.

Pot F. (2011). "Workplace innovation for better jobs and performance". International Journal of Productivity and Performance Management, 60 (4), 404-415.

Pot F., Totterdill P. \& Dhondt S. (2016). "Workplace innovation: European policy and theoretical foundation". World Review of Entrepreneurship, Management and Sustainable Development. 
Ramstad E. (2009a), "Promoting performance and the quality of working life simultaneously". International Journal of Productivity and Performance Management, 58 (5), 423-436.

Ramstad E. (2009b), "Developmental evaluation framework for innovation and learning networks," Journal of Workplace Learning, Vol.21 No.3, pp.181-197.

Sharpe A. and Totterdill P. (1999) An Evaluation of the New Work Organisation in Ireland Programme. Dublin: Irish Productivity Centre.

Shortell S. M., Zimmerman J. E., Rousseau D. M., Gillies R. R., Wagner D. P. and Draper E. A., (1994). “The performance of intensive care units: Does good management make a difference?" Medical Care 32(5) 508-525, American Public Health Association, Lippincott, Williams and Wilkins, PA, USA.

Sisson K. (2009), Improving work organisation - the case for a regional action programme. Policy position paper for East Midlands Regional Development Agency. Warwick: University of Warwick.

Sisson K. (2014), The UK Productivity Puzzle - is employment relations the missing piece? Acas Policy Discussion Papers, September.

Teague P. (2005), “What is enterprise partnership?” Organization, Vol.12 No. 4, pp.567-589.

Totterdill P. (2015) “Closing the Gap: 'The Fifth Element' and Workplace Innovation.” European Journal of Workplace Innovation, 1,1, January 2015.

Totterdill P., (2017) "Workplace Innovation as Regional Economic Development: Towards a Movement?" International Journal of Action Research, (02) 129-153.

Totterdill P., Cressey P. and Exton R. (2012), "Social innovation at work: workplace innovation as a social process." In: Franz, H-W, Hochgerner, J., Howaldt, J. (eds) Challenge Social Innovation. Potential for business, social entrepreneurship, welfare and civil society. Berlin: Springer, 241-259.

Totterdill P., Dhondt S. and Milsome S. (2002). Partners at work? A report to Europe's policy makers and social partners. Nottingham: The Work Institute. Available at

http://www.ukwon.net/files/kdb/0415f02fe854733c3d8e650791297cb0.pdf

Totterdill P., Exton O., Exton E., Gold M. (2016) "High-performance Work Practices in Europe: Challenges of Diffusion, ,.European Journal of Workplace Innovation, 2, 1.

Totterdill P., Exton O., Exton R., Sherrin J., (2009), Workplace Innovation in European Countries. Report to KOWIN (Korean Ministry of Labour). Nottingham: UKWON. Available at http://www.ukwon.net/files/kdb/0f4aebcbc007683b62ac4aff825f5219.pdf

UKCES (2009) "High Performance Working: A Synthesis of Key Literature". Evidence Report 4. Wath-uponDearne: UKCES.

Wilson R., Hogarth T. , Bosworth D., Dickerson A., Green A., Jacobs C., Keep E., Mayhew K. and Watson S. (2003) "Tackling the Low Skills Equilibrium: A review of issues and some new evidence". A report for the DTI. Coventry: IER, University of Warwick.

Wright J. and Sissons P. (2012), The Skills Dilemma: Skills Utilisation and Low-Wage Work. London: The Work Foundation 


\section{About the authors:}

\section{Rosemary Exton}

Director, Workplace Innovation Europe CLG, United Kingdom / Ireland

20 Fletcher Gate, Nottingham NG1 2FZ, UK

Email: rosemary.exton@,workplaceinnovation.eu

\section{Peter Totterdill}

Director, Workplace Innovation Europe CLG, United Kingdom / Ireland

Visiting Professor, Kingston University London and Mykolas University Vilnius

20 Fletcher Gate, Nottingham NG1 2FZ, UK

Email: peter.totterdill@,workplaceinnovation.eu

\section{Biographical notes for authors:}

Rosemary Exton is a Director of Workplace Innovation Europe CLG, an international not-for-profit company committed to stimulating and resourcing better ways of working. She specialises in employee involvement in innovation and improvement, employee voice, and trade union participation in workplace innovation.

Peter Totterdill, Ph.D, is a Director of Workplace Innovation Europe CLG, an international not-for-profit company committed to stimulating and resourcing better ways of working. He is also a Visiting Professor at Kingston University London (UK) and Mykolas Romeris University (Lithuania). Peter's area of expertise includes work organisation, employee-driven innovation, and public policy. 